\title{
THE PHILOSOPHY OF OUR IMMIGRATION LAW
}

\author{
LouIs L. JAFFE*
}

\section{I}

\section{Immigration Policy Before I92I}

The battle over immigration policy has been waged in terms which conceal the true nature of the difficulty. ${ }^{1}$ To the opponents of the McCarran-Walter Act, ${ }^{2}$ that law is the child of iniquitous prejudice and hysterical fear. It is defended, on the other hand, as a bulwark against racial deterioration and political subversion. The writer takes his stand with those who denounce the law. Its quota provisions were born in racial prejudice. They give needless offense to many of our citizens and to the people of other countries; they bedevil the conduct of our foreign relations and add nothing to our public welfare. The provisions dealing with the qualifications of particular immigrants and with the deportation of aliens already here are likewise marred by cruelties which reflect a combination of elements: hysterical responses to current dangers, xenophobia, and the downright callousness of the unimaginative. But the writer is inclined to believe that the difficulty lies even deeper than these conflicts of attitude and mood. It is the basic difficulty of defining a positive role for immigration sufficiently persuasive to win popular support. Absent a positive philosophy, absent a clearly held view of the function of immigration, the ever-present impulses of fear and hate rush into the vacuum.

Until 192r, the total of immigration into the United States was unlimited. Toward the close of this period, minimal personal qualifications were imposed. It is sometimes questioned whether unlimited immigration was a conscious policy or simply the consequence of failure to formulate policy. It would seem clear, however, that it was a deliberate policy. The country has never been free of xenophobia, and there was agitation, from time to time, to restrict immigration; yet, this agitation came to naught. Unlimited immigration was the logical concomitant of basic American policy. The United States was committed very early to its philosophy of "manifest destiny." The goal was the occupation and settlement of the country from coast to coast and the stabilization of the northern and southern boundaries. This policy required men as soldiers and as workers. Immigration, therefore, satisfied needs to which government gives highest priority: economic well-being and defense.

- A.B. 1925, Johns Hopkins University; LL.B. 1928, S.J.D. I932, Harvard University. Mcmber of California and New York bars; Byrne Professor of Administrative Law, Harvard University, since 1950, Author, Judicial Aspects of Foreign Relations (I932); Cases and Materials on AdministraTIVE LAW (1953). Contributor to legal periodicals.

1 The quota policies of the present law and proposals for reform are considered in Schwartz, American Immigration Policy, 55 ColuM. L. Rev. 31 I (1955).

${ }^{2} 66$ StAT. 163,8 U. S. C. $\$$ I101-503 (1952). 
The constant infusion of newcomers with a high proportion of matured individuals, combined with enormous undeveloped resources, gave unusual impetus to the production of wealth and laid the basis for the expanding market which we demand today as the condition of prosperity.

But possibly the more relevant inquiry for our present concern is whether immigration was seen as serving social and ideological purposes distinct from the economic. It is, of course, a major proposition of American history that the most influential of the founders were activated by noneconomic motives. The Puritans sought a spiritual haven, the power and opportunity to found a religious commonwealth free of alien control. But it does not follow that they envisioned their new home to be perpetually a haven for all those seeking escape and greater fulfillment. Indeed, it has been the oldest stocks that have been most hostile to later-day immigration. In time, however, the country filled up with enormous complements of people from every land. These people, in building up their image of the country, inevitably took account of its racial medley. The peoples of Europe were aware that racial juxtapositions were a sinister source of social conflict, a threat to the security of the country. The most fruitful strategy to combat the threat was to transform the weakness into a strength. The glory of America-its greatness, its enthusiasm, its richness-was to be precisely the characteristic of racial diversity. The most popular version of this image was the Melting Pot. In its purifying fires would be fused the sinews of a finer race.

The present day version is apt to emphasize unification a little less and diversity a little more, perhaps because our experience has demonstrated the persistence of racial variation. But in any version, the multiplicity of peoples becomes one of the positive features of the image of America. America becomes the promised land for all the rest of the world, and this is asserted to be a chief source of its strength. Thus, it must, Anteas-like, continually renew its strength by admitting new people. Not all, perhaps not even a majority, of Americans hold this view. It has been vigorously rejected, particularly by individuals of the older stocks who have no sense of being a racial minority and think of themselves as distinctly and uniquely American. There can be little doubt that the most powerful affirmation of the Melting Pot and of racial diversification comes from those who are still racially conscious. It is they who form the largest pressure groups for the continuation of immigration.

It appears to be clear that by the usually accepted criteria, our past immigration policy has been astoundingly successful, though, as will be shown below, we must acknowledge some qualifications. There is no need to dwell on the tremendous achievement of the American economy. Not only has it succeeded in producing a mass standard of living higher than any known in history, but it shows a capacity for constant adaptation and expansion. All this argues that judged by the standard of wealth and prosperity, our immigration policy has been vindicated. But the economic success obviously implies an underlying and pervasive social achievement. 
Wealth cannot be produced merely by bringing together men, material, and machines. The production of wealth implies not a mechanical, but a chemical or organic transformation of the elements. Men must work together. They may, of course, do this at the lowest level under the spur of necessity. But in the American achievement, there has been a convinced cooperation. There has been a general participation in technical development and, what is more important, a willingness to take the chances and immediate risks of such development. This testifies to social cohesion, to trust in the society, surely one of the most crucial criteria for measuring a society's success.

One is tempted to compare the United States with Canada and Australia, in which, at least until recently, immigration has been limited to the dominant pioneer stocks. There is, one would suppose, even more social cohesion in these countries, particularly Australia. But one is struck-again, this may be more true of Australia than of Canada-by the comparative conservatism of its economy and, even more, of its social system. Far from home, nearly encircled by the alien Orient, this small group of Englishmen, living in the vast empty spaces of Australia, look to Britain and its tradition. For the Americans, there has been no authoritative home, and they have had to look to each other and to the future. The situation has called forth, in high degree, both cooperation and competition and would seem to have released an outpouring of creative impulses. It is debatable, surely, whether America has produced a significant and original higher culture.- But whatever its absolute achievement, its culture appears to be more vibrant, more colorful, more energetic, than those of the new lands which have limited immigration to the original pioneering stock. The story of military defense is much the same. In each of our great wars, there has been apprehension that one or another racial group was divided in its allegiance. But ultimately it appeared that the number of such persons was not significant.

It would not be honest, however, to omit reference to certain facts which might be thought to qualify this picture of success. It has already been noted that the figure of the Melting Pot is no longer as popular as it once was. It is more correct-and in the mind of some, morally superior-to speak of pluralism. The premise is that everyone will satisfy the basic minima of American citizenship. But beyond that, each will be free to practice his diversities, among which may be those of a racial character. This, like the Melting Pot, is thought of as not merely tolerated, but positively beneficial. It "enriches" the society. It intensifies the satisfactions of individual expression. But it must be confessed that racial diversity has at times expressed itself in disturbing ways. Certain racial groups, while putting America first, have quite understandably put their homeland second, and have, on occasion, constituted themselves a lobby for their homeland in the arena of foreign affairs. Thus, the Irish, throughout the nineteenth and early twentieth century, attempted to exert an influence upon foreign policy, motivated primarily by Irish rather than American interests. President Truman has recently expressed a 
similar opinion with respect to Jewish intervention in American policy toward Israel and the Arab states. It is not, of course, a question here whether the views were right or wrong. The point is simply that judging immigration by the criterion of social cohesiveness, we must count these facts as qualifications of more general conclusion.

And within the country there are evidences of problems created by racial juxtaposition. The greatest of these, of course, is that between white and Negro. It would, to be sure, be an outrageous irony to characterize this as a result o- "immigration." But it does testify to the proposition that however great may be our capacity to fuse races, there is a limit beyond which serious problems arise, though it may be true, if paradoxical, that the great challenge of the Negro problem has enabled us to take more in stride lesser problems of racial juxtaposition. A somewhat smaller but similar case is the migration of Puerto Ricans into New York City. A more subtle phenomenon, if it is, in fact, a definable phenomenon, is the situation of hostility in which certain of the Irish would appear to be on one side and the Jews and Protestants on the other. The phenomenon which we loosely call McCarthyism may, in some measure, reflect a mutual distrust between these two groups.

The thesis has been, from time to time, propounded that immigrants-or certain foreign stocks-are more prone to crime than natives of the old stocks. The evidence for this thesis has been hotly criticized and the thesis itself attributed more to racial prejudice than to a scientific concern for the truth. But whatever the truth, it is doubtful that it can be established by statistics. Yet, the thesis may contain germs of truth. Today, the inquiry is pursued not by amassing statistics, but by observing the social situation of immigrants and their offspring. We observe, for example, that conflicts may develop between the immigrant and his child. The child may scorn his parents because they are foreign. But the child rejecting the authority and support of his family may find no decent substitute in the new society. The dominant native groups, socially and economically exclusive, often give him no warm welcome, particularly if he is of a lower economic or social class. He may become rootless, aimless, dispirited, and seek satisfaction in the camaraderie of the spiritually dispossessed. It is possible, indeed, to argue that this "rootlessness," this alienation, affects, in some measure, our whole society. Precisely because we are a heterogeneous people without a common racial and cultural tradition, we may be more prone than some other peoples to fall into the limbo between the rejected old and the not-quite-learned new. We are, as we have already noted, an amazingly flexible, mobile people. This is the source of our remarkable economic and productive strengths. But this same restless mobility may become a constant yearning for titillation. Perhaps this is a price we must pay for our virtuosity. The writer would venture to say that the usual American would not find the price too high.

The writer would, in any case, conclude that the problems of race are practically irrelevant to the formulation of immigration policy in the immediate future. It is 
common ground that the annual quota will not be more than 250,000 . This amount will, in turn, be divided up among the various races and nationalities. The character of our own people has now, whether good or bad, whether polyglot or a new fusion, been determined, and it is far-fetched to believe that a few thousand more or less of any one stock would have an appreciable impact.

\section{II}

\section{The Present Policy}

The basic policies of the present law-the McCarran-Walter Act of 1952-were established by the Act of $1924 .{ }^{3}$ The effect of this is to fix an annual total of about 156,000. Each of eighty-five countries receives an annual quota, or part of the total. Any nation's quota is equal to one-sixth of one per cent of the number of persons in our 1920 population who were of that origin. ${ }^{4}$ It was the avowed intention of this law to favor the so-called Nordic race and to disfavor the Slavic, Mediterranean, and Jewish stocks. Thus, the annual quotas for the United Kingdom, Germany, and Ireland are 65,000, 25,000, and 17,000 respectively. The annual quotas for Poland and Italy are 6400 and 5600 , respectively. The northern and western European countries have 125,000 numbers out of the total 156,000. It was sometimes argued in support of this policy that the Nordic races are "superior," at other times, more guardedly, that their character and culture are more consistent with the ideal or at least established concept of the American.

This ill-conceived piece of legislation has been an easy mark for scornful criticism, which has been able to point out that the so-called "scientific" support for this "racist" theory is unsatisfactory. There would, however, seem to be a core of truth in the racist theory, a truth, however, which, in the context, appears to the writer to be irrelevant. A society composed exclusively, for example, of English Puritans would be startlingly different, it may be supposed, from one composed of equal parts of English, Puritan, Mohammedan Arab, Confucian Chinese, Palestinian Jew, and Parsee Sun Worshipper. The Parsee might find the latter a more congenial society,

${ }^{3}$ Act of May 26, 1924, c. I90, 43 STAT. I53.

"The national-origin quotas evolved as follows: Act of May 19, 192I, c. 8, $\$ 2$ (a), 42 STAT. 5 : "... the number of aliens of any nationality who may be admitted under the immigration laws of the United States in any fiscal year shall be limited to 3 per centum of the number of foreign-born persons of such nationality resident in the United States as determined by the United States census of rgro."

Act of May 26, r924, c. I90, $\$$ I (a), 43 STAT. 159: "The annual quota of any nationality shall be 2 per centum of the number of foreign-born individuals of such nationality resident in continental United States as determined by the United States census of 1890 , but the minimum quota of any nationality shall be roo."

The Immigration and Nationality Act of 1952, $\$ 20 \mathrm{I}, 66$ STAT. 175, 8 U. S. C. I151(a): "The annual quota of any quota area shall be one sixth of $x$ per centum of the number of inhabitants in the continental United States in 1920, which number, except for the purpose of computing quotas for quota areas within the Asia-Pacific triangle, shall be the same number heretofore determined under the provisions of section $x I$ of the Immigration Act of $x 924$, attributable by national origin to such quota arca: Provided, that the quota existing for Chinese persons prior to June 27, 1952, shall be continucd, and, except as otherwise provided in section $1152(e)$ of this title, the minmum quota for any quota arca shall be one hundred." 
but, by the same yardstick, the Puritan, too, might be allowed his preference. But as has already been indicated, in I924, the country was not composed exclusively of Puritan or Nordics. Whatever might have been the predominance, it was irrevocably mixed for better or worse, and it should have been difficult to believe that the particular racial distribution of the 150,000 immigrants to be admitted each year would have any significant impact on the American racial character. Under such circumstances, the policy of 1924 became the merely gratuitous expression of a prejudice. It gave, no doubt, considerable satisfaction and perhaps increased security to those who held the prejudice, but at the cost of a deep sense of injury to a vast number of American citizens and to a considerable number of countries with which we must continue to do business. One thing, then, seems very clear. Whatever our immigration policy, however difficult it may be to formulate any positive function for immigration, however, therefore, arbitrary it may or must be in the absence of an adequate philosophy, it should not be based on notions of the relative value of race or national origin. The least we can ask of the immigration law is that it do no unnecessary harm.

It is a rather puzzling feature of the 1924 settlement that immigration from the Americas was not restricted at all. The two main sources, of course, of that immigration are Canada and Mexico. There is very little in the statutory history which purports to explain this. The original bill designed to suspend all immigration did also apply to the Americas. The senate bill, which finally prevailed, excluded the American countries from quota limitation, but there is no explanation of this in the committee report. However, the emphasis in the report is on the unprecedented amount of "new" immigration, ${ }^{5}$ and there can be no doubt that the principal reason for the legislation was to exclude eastern and southern Europeans. The exemption of the western hemisphere has remained in all later acts. It is probably explained by a number of motivations and assumptions: first, as a symbol of American solidarity, with particular emphasis on Canada; second, by the reliance of southwestern growers on Mexican labor, though from a strictly legal position, this need is met by legislation for temporary immigration. ${ }^{6}$

The policy of 1924 seems to have been basically a negative one. The emphasis was first, on limitation of the total number; and secondly, on putting an end, for all practical purposes, to immigration from certain countries. But why should there be any immigration at all? And if there was to be immigration, why precisely 150,000? This question was, in a sense, asked in 1917 and given a rather vague and inconclusive answer. There was, at that time, as an initial reaction to the immigration "problem," a proposal to stop immigration entirely for four years (with a few limited exceptions). The house committee later suggested such a bill, but the senate committee rejected it primarily, it said, because there was no such emergency as to warrant such a radical change, but incidentally because it would "inevitably work

\footnotetext{
${ }^{5}$ See tables in note 29 infra for over-all immigration figures.

${ }^{\circ}$ Agricultural Act of 1949,63 STAT. 1051 (1949), 7 U. S. C. $\S$ I446 (1952).
} 
hardship, if not disaster, to many sections of the country." The committee noted that as a result of the war, there was an unsatisfied need for common farmer labor, and despite unemployment, there was, in the opinion of "competent writers," an estimated labor shortage of $4,000,000$. The theory seemed to be that the national economy needed continued immigration to satisfy common labor needs. This position was not argued in any detail, however, though it is somewhat reflected in the later 1924 Act, which did suggest this and one other positive motivation. It set up, for example, two preferences within each quota: the first for certain close family relatives of citizens, the second for agriculture. ${ }^{8}$ Those preferences, however, were rather narrowly conceived; and in any case, it was provided that the preferences should not absorb more than fifty per cent of the quotas. It would seem clear, then, that whatever concept these preferences expressed, they would not account for having fixed the total at 150,000 .

The drafters of the policy of 1924 may well have concluded that however difficult it might be to formulate reasons for immigration, complete embargo on movement to this country would have been unthinkable. Suddenly to stop this vast flow of peoples might have administered to opinion here and abroad a shock of an almost physical character. For over two centuries, the policies of the United States-imperial, colonial, and republican-had built up great expectations in the hearts of the peoples of the world and in their kin in this country. To cut off all movement of people would be to introduce a rigidity, an imperviousness, that might seem almost contrary to the nature of things. Now, this feeling would not dictate any particular total of immigration. Therefore, an arbitrary number must be chosen. Indeed, when we come finally to try for a formulation for the future, it will appear that if a number must be set in the statute itself, the number will have to be arbitrary.

The policy of 1924 is still the basic standing law. It was adopted as the foundation of the McCarran-Walter Act of 1952. Some of the implications of the earlier statute have been more fully developed in the later statute. This is particularly true of the development of the preference categories. Thus, the preference for skills is extended to any which are determined by the Attorney General "to be needed urgently," and "to be substantially beneficial prospectively to the national economy, cultural interests, or welfare of the United States." unification are applied not only to certain relatives of citizens, but to relatives of aliens as well; and these preferences will be permitted to exhaust the entire quota. ${ }^{10}$ The family reunification motif is further emphasized by the provision that spouses and unmarried minor children of citizens enter as nonquota immigrants. ${ }^{11}$ This also expresses the idea that the citizen is free to marry where and whom he pleases.

\footnotetext{
${ }^{7}$ Emergency Immigration Legislation, S. REP. No. 789, 66th Cong., 3d Sess. 6 (1921).

${ }^{8}$ Act of May 26, 1924, c. 190, \$6(a), 43 Stat. 155.

${ }^{\circ} 66$ StAT. I78, 8 U. S. C. $\$$ II53 (I952).

${ }^{10}$ Ibid.

${ }^{11} 66$ STAT. I80, 8 U. S. C. \$ II55 (1952).
} 
It would be a mistake, however, to limit our view of American immigration policy to the provisions of the basic standing law. The ad hoc refugee-relief legislation has somewhat altered policy both as to total numbers and the racial composition of the total. First, a word as to the somewhat ironical operation of the basic law in these two respects. The British, with the largest, and the Irish, with the third largest quota, have not been overeager to avail themselves of their opportunities. ${ }^{12}$ Thus, for a number of years, these quotas have been very much undersubscribed, whereas the pressure of immigration from the disfavored countries has continued to be intense, and the quotas always oversubscribed. Since the unused numbers are not reassigned to any other country and are not carried over to the following year, the total immigration under the basic law has, in the last few years, been less than the statutory maximum. This phenomenon is usually pointed to by the critics of the law to show that it does not fulfill even its own theory and is somehow, for this reason, absurd. But it is doubtful that so long as the disfavored people are so drastically excluded, it very much impairs the law's theory that there are fewer Englishmen than we are willing to receive. Nor would it seem to be contrary to the purposes of the law that, thereby, the maximum is not attained. The maximum, as we have said, seems to express an arbitrary limit rather than a positive need.

The refugee-relief legislation does, however, introduce modifications of policy. The first of these acts, the Displaced Persons Act of $1948,{ }^{13}$ provided for the admission of 400,000 persons displaced by war and revolution. As a result, in the years I950, I951, and I952, for example, the total immigration from quotas countries was 197,460, I56,547, and 194,247 , respectively. ${ }^{14}$ The act represented a substantial departure from the existing national-origins quota provisions. Thus, under it, there have been admitted, in the four years in which it operated (1948-52), for example, 132,000 Poles (regular quota 6,400) and 33,000 Yugoslavians (regular quota 933). The statute required that one-half of the regular annual quota be "mortgaged" until the overage should be discharged, but despite this unfortunate device, the immediate operation of the act worked a substantial variation from the particular quotas in-

12 Annual Qutotas:

Great Britain and Northern Ireland Ireland
$65,36 \mathrm{r}$

$x 7,756$

\begin{tabular}{lrrrrrrr}
\multicolumn{2}{l}{ Quota Immigrants } & Admitted & Annually: & & & & \\
& 1948 & 1949 & 1950 & 1951 & 1952 & 1953 & 1954 \\
Great Britain & 27,774 & 23,543 & 17,194 & 15,369 & 20,368 & 24,219 & 21,092 \\
Ireland & 7,444 & 8,505 & 6,444 & 3,810 & 3,819 & 4,635 & 5,169
\end{tabular}

U. S. Imimigration and Naturalization Service Ann. Rep. table 7 (r949-1955).

${ }^{13} 62$ STAT. Ioog (1948), as amended, 50 App. U. S. C. $\$ \$ 1951-65$ (1952).

${ }^{14}$ Immigration under the Immigration Act of 1924 and the Displaced Persons Act of 1948 :

$\begin{array}{lrrrr} & 1949 & 1950 & 1951 & 1952 \\ \text { Total } & 113,046 & 197,460 & 156,547 & 194,247 \\ \text { Of these, displaced persons } & 39,734 & 127,120 & 95,920 & 77,196\end{array}$

U. S. Immigration and Naturalization Service Ann. Rep. 24 (I950); id. at i8 (1952). 
volved. ${ }^{15}$ The Refugee Relief Act of 1953, as amended, ${ }^{10}$ substantially increased the Italian, Greek, and Dutch quotas in the family preference category. ${ }^{17}$ The analysis and operation of this latter act, however, will be undertaken in the next section of this paper.

\section{III}

\section{The Searce for a New Policy}

It is often assumed, particularly by opponents of the McCarran-Walter Act, that the policy up to I92I established and exemplified a policy inherent in the concept of America. There may be, and it would seem that there are, certain underlying motivations of that policy that are still valid. But it must be admitted, I think, that the conditions upon which that policy was based have been drastically altered. The policy of unlimited immigration was dictated by economic needs which have now been substantially satisfied. There may, perhaps, remain certain marginal economic considerations. Beyond that, we have seen that the original motivation of some of

${ }^{10}$ The total number of displaced persons admitted (1948-52) was 399,698, nearly all of whom were charged to quotas.

Selected Countries:

Country of birth
Poland
Latvia
U.S.S.R.
Germany
Yugloslavia
Lithuania
Greece
Hungary
Estonia

Number admitted
$132,85 \mathrm{I}$
35,734
34,941
$6 \mathrm{r}, 273$
33,026
24,603
10,271
16,032
10,186

Year to which $50 \%$
of quota used
2000
2274
1980
2009
2089
$20 \times 3$
.2146

U. S. Immgration and Naturalization Service, AnN. Rep. 23 (1953).

${ }^{16} 67$ STAT. 400 (1953), as amended, 50 App. U. S. C. A. \$ 1971 (1955 Supp.).

17 The following composite table shows total Italian immigration under the various acts. The regular quota has varied from 5,802 to 5,645 .

\begin{tabular}{|c|c|c|c|c|c|c|}
\hline & \multicolumn{2}{|c|}{ Quota Immigration } & \multicolumn{3}{|c|}{ Nonquota Immigration } & \multirow[b]{2}{*}{ Total" } \\
\hline & Total & $\begin{array}{c}\text { Displaced } \\
\text { Persons Act } \\
\text { of } \mathrm{I948}\end{array}$ & $\begin{array}{c}\text { Family* } \\
\text { Unification }\end{array}$ & $\begin{array}{c}\text { Displaced } \\
\text { Persons }\end{array}$ & $\begin{array}{c}\text { Refugee } \\
\text { Relief Act } \\
\text { of } 1953\end{array}$ & \\
\hline $\begin{array}{l}1946 \\
1947 \\
1948 \\
1949 \\
x 950 \\
1951 \\
1952 \\
1953 \\
1954\end{array}$ & $\begin{array}{l}x, 253 \\
5,023 \\
5,624 \\
5,478 \\
5,829 \\
4,592 \\
5,954 \\
4,98 x \\
6,146\end{array}$ & $\begin{array}{r}7 \\
478 \\
504 \\
640 \\
4 \\
27\end{array}$ & $\begin{array}{l}2,608 \\
9,469 \\
9,974 \\
5,610 \\
3,733 \\
2,460 \\
2,844 \\
4,116 \\
7,788\end{array}$ & $\begin{array}{r}2 \\
40 \\
261 \\
265\end{array}$ & 617 & $\begin{array}{r}3,886 \\
x 4,557 \\
x 5,801 \\
x 1,645 \\
9,839 \\
7,348 \\
9,306 \\
9,701 \\
15,201\end{array}$ \\
\hline
\end{tabular}

* Includes spouses and minor unmarried children of citizens.

* Includes other numerically insignificant nonquota immigrants: ministers, professors, ctc.

U. S. Immigratton and Naturalization Service ANN. Rep. table 6 (1947-1955). 
the migrations, as, for example, to New England and Pennsylvania, and the very fact of the later massive migrations of many races gave rise to a mystique of America which aroused expectations of further migration both here and abroad. This mystique, however, has always been strongly opposed by large and important groups in the community. No one, in fact, denies that the policy of unlimited immigration is obsolete, and it, therefore, becomes a problem to determine what, if any, of the older implications are still pertinent and, more broadly, what functions of immigration are persuasively valid for the present and immediate future. ${ }^{18}$

There are, arguably, still certain marginal economic uses for immigration. In an ideal world of complete freedom of movement, individuals would go where their skills were most needed. In our actual world, there may arise a demand for skills which cannot be immediately satisfied. Perhaps more incentives and facilities for training is the long-term answer. But, in the meantime, immigration may fill the gap. The immigrants may be, incidentally, the bearers of technical variations or improvement. The same argument for immigration has been urged for unskilled or semiskilled workers who are in short supply in this country, such as shepherds ${ }^{19}$ or house-servants.

This argument is, however, of doubtful validity. The forces which cause Americans to avoid these jobs would operate in a very short time on the immigrants, and it would seem that our society must find some more basic solution for the provision of these or substitute services. It is true, of course, that the immigrants could be admitted on temporary visas with an expressed or implied understanding that they would perform certain work. ${ }^{20}$ In the Southwest, the Mexicans who cannot satisfy the conditions for permanent immigration are admitted for a period of months to assist in the harvesting of crops. ${ }^{21}$ This is not a very satisfactory expedient. It

\footnotetext{
${ }^{18}$ The most carcfully developed and thought-through substitute for the present quota provisions is the bill introduced by a group of legislators led by Senator Lehman. The writer of this article was a member of the drafting group which developed this bill. He generally concurs with its proposals, but with possible differences in emphasis and commitment on certain points. What he says in this article does not necessarily represent the consensus of the group or the thought of any other member of the group. The bill was last introduced in the $84^{\text {th }}$ Congress, First Session, as S. 1206.

${ }^{10}$ Thus, special provision has been made for admitting, each year, a certain number of shepherds from countries whose quotas have been exhausted and charging them against future quotas. This legislation has been thought to be the work of Senator McCarran on behalf of the Nevada sheep industry. 64 STAT. 306 (1950) (250 to be admitted under the act); 66 STAT. 50 (1952) (500); 68 STAT. II45 (1954)
} (385).

${ }^{20}$ Under the Displaced Persons Act, nearly all classes of displaced persons are admitted only after assurance is given "that such person, if admitted, into the United States, will be suitably employed without displacing some other persons from employment. ..." 62 STat. roro (1948), as amended, 50 App. U. S. C. $\S$ I952(c) (r952). And in order to control the employment of these persons, every such person is required to make four half-yearly reports to the Displaced Persons Commission, giving details of his employment. 62 STat. I013 (1948), 50 App. U. S. C. $\$ 1958$ (1952). Under a 1950 amendment, the immigrant is required to take an oath that he accepts and agrees in good faith to abide by the terms of employment provided in the assurance on which the visa issues. 64 STAT. 224 (r950), 50 App. U. S. C. \$ 1955 (1952).

21 The admission of Mexican agricultural laborers was authorized under proviso 9 of $\S 3$, Immigration Act of 1917, c. 29, 39 STAT. 879: ". . . the Commissioner of Immigration and Naturalization with the approval of the Attorney General shall issue rules and prescribe conditions, including exaction of such bonds as may be necessary to control and regulate the admission and return of otherwise inadmissible 
fosters conditions of peonage, and it is difficult to enforce the undertaking to leave the country at the appropriate time. To be sure, if the need for a particular service is sufficiently acute, permanent or temporary immigration, even with all its difficulties and drawbacks, may provide an answer. Thus, we have, since 1917, relied on Mexican labor to work and harvest crops in the Southwest. Both France and England have used immigration to make up a deficit of coal miners. The French, by treaty with Poland, devised legal sanctions to keep the worker on the job.2 Even in the absence of a sanction, however, the immigrant is, perforce, required at least to begin his work at the mine and may be kept there by circumstance for some time because of the normal disinclination to move, the special disabilities of the immigrant in a new country, and the isolated character of the coal mine. And if, despite these factors, the immigrant drifts away from the mine, the loss can be made up by new recruits.

To the extent that the economic function of immigration rests on this need for special categories of workers, it presents one prime problem in its precise formula-

aliens applying for temporary admission." Tit. V, $\$ 501$, of the Agricultural Act of 1949, $6_{3}$ STAT. I05I (1949), as added, 65 STAT. II9 (195I), 7 U. S. C. $\$ 1461$ (I952), deals further with this subject: it permits the Secretary of Agriculture to supply agricultural workers from the Republic of Mexico, subject to certain conditions set forth in the other sections and under regulations of the Attorncy General. The new rules and regulations implementing the Immigration and Nationality Act with respect to the admission of agricultural workers under special legislation, 8 C. F. R. $\$ 475$ (1952), provide as follows:

"§475.2. Period for which admitted. An agricultural worker may be admitted to the United States as a non-immigrant pursuant to section IOI(a)(15)(H) of the Immigration and Nationality Act: Provided: .... (b) that no maintenance of status or departure bond shall be required and [the statute forbids such bonds]; (c) that the period of temporary admission shall be subject to immediate revocation, without notice, by the district director of the district having jurisdiction over the place of the alien's employment upon: ( $I$ ) Failure of the agricultural worker to maintain his status as such by accepting any employment or engaging in any activities not specifically authorized at the time of his recruitment and temporary admission; (2) Withdrawal of the employer's certification because of violation of Title $V$ of the Agricultural Act of 1949, as amended, or the Migrant Labor Agreement of 195r, as amended, or individual work contract made thereunder, as specified in $\$ 475.4$ (b); or (3) Determination and notification by the Secretary of Labor that sufficient domestic workcrs who are able, willing, and qualified are available at the time and place needed to perform the work for which such workcrs are employed, or that the employment of such workers is adversely affecting the wages and working conditions of domestic agricultural workers similarly employed, or that reasonable efforts have not been made to attract domestic workers for such employment at wages and standard hours of work comparable to those offered to foreign workers; or (4) Termination of the Migrant Labor Agrecment of 1951, as amended, prior to December 31,1953 .

"\$ 475.4. Compliance by employer. ... (c) If a Mexican agricultural worker leaves his cmployment without proper authorization, the employer shall report such departure immediately or within five days thereof to the district director having jurisdiction over the reception ecnter at which the worker was recruited. Such notification shall contain $(\mathrm{I})$ the individual worker's name, as shown in the employer's copy of the contract; (2) the worker's Form I-rooa number; (3) the location of the reception center at which the worker was originally contracted; and (4) the date the worker left the employcr."

The problem of Mexican agricultural labor is considered in greater detail elsewhere in this symposium. See Hadley, A Critical Analysis of the Wetback Problem, stupra 334-57.

${ }^{22}$ See Sauvy, European Migrations: Regulations and Treaties, 22 Annals 22, 27 n. 4 (1949). Under the Australian law also, the authorities may expel an alien who came in pursuance of a special arrangcment and fails to observe its conditions. Australia Immigration Act 190I-1940, $\$ 4$ (B)(d). Similarly, under the Canadian Immigration Act of I952, CAN. Rev. STAT. c. 325, § 8(I) (1952), the government has full discretion to grant and cancel immigration permits. 
tion. It does not afford the basis for any previously determined total of immigation in any one year or period. This characteristic, as a matter of fact, it shares with most other potential functions of immigration. The indicated solution would be to delegate power to admit immigrants as the need appeared, but whereas England, Canada, and Australia, for example, grant almost unlimited discretion to their immigration authorities, Congress, as has been seen, insists on establishing the total number to be admitted, the distribution of that amount among the countries of the world (quotas), and the process for qualifying individuals within the quotas. It must be concluded, therefore, that the economic functions of immigration are today marginal and relatively unimportant, ${ }^{23}$ and that almost any conceivable immigration policy likely to be adopted must be justified in noneconomic terms. This would appear to represent a complete reversal of the earlier policy, the purpose of which was almost entirely economic, the other alleged functions being essentially by-products. It is this radical reversal that creates the dilemma.

We must proceed, then, to explore and evaluate potential functions of a noneconomic character. The most immediate and obvious, because already expressed in the law, is family reunification. This, of course, satisfies a need of persons already in the country, some of them citizens, some of them resident aliens. As to some of the relationships, this need is limited by the number of families that have not yet been reunited. ${ }^{24}$ But the free admission of spouses and children of citizens is not thus restricted. By reason of it, an American citizen may without impediment marry a noncitizen abroad. ${ }^{25}$ These nonquota provisions should be extended to

${ }^{23}$ The numbers admitted under the skills preference are comparatively few-e.g., 2,456 in 1954. This is about $2 \frac{1}{2} \%$ of the total; the preference is permitted to absorb $50 \%$. U. S. IMmIGRATION and Naturalization Service Ann. Rep. table $7 \mathrm{C}$ (1955). The number of temporary agricultural laborers admitted from Mexico is, however, considerable:

$\begin{array}{rrrrr}195^{\circ} & 1951 & 1952 & 1953 & 1954 \\ 1 \times 6,05^{2} & 1 \times 5,74^{2} & 223,54 \mathrm{I} & 178,606 & 213,763\end{array}$

U. S. Imimigration and Naturalization Service AnN. Rep. 25 (1952); id. at 20 (1954). Furthermore, it is well known that enormous numbers enter illegally, characteristically by wading or swimming the Rio Grande; hence, the name given them of "wetbacks."

The text takes no account of all the possible economic arguments that might be made for substantial immigration based on intricate economic and demographic analysis, estimates, etc. Such arguments are far too abstract and controversial to provide a convincing basis for legislation. For a more extended discussion of the economic aspects of immigration, see Spengler, Economic Aspects of Immigration into the United States, supra 236-55.

${ }^{21}$ Quota Immigrants under the Immigration and Nationality Act-Family Unification:

Parents of United States citizens $x 954$

Spouses and children of resident aliens

2,783

Children over 21 years of age, or married, of a

United States citizen

U. S. Immigration and Naturalization Service Ann. Rep. table 7 C (i955).

${ }^{25}$ Nonquota Immigrants (not including nonquota countries):

\begin{tabular}{l|r|r|r|r|r|r|r|r|r}
\hline \hline & $\mathrm{I} 947$ & $\mathrm{I} 948$ & $\mathrm{I} 949$ & $\mathrm{I950}$ & $\mathrm{I951}$ & $\mathrm{I952}$ & $\mathrm{I953}$ & $\mathrm{I954}$ & $\mathrm{I955}$ \\
\hline $\begin{array}{l}\text { Husbands of United States citizens. } \\
\text { Wives of United States citizens.... }\end{array}$ & $5 \mathrm{I}, 698$ & 647 & 3,239 & $\mathrm{I}, 459$ & 822 & 793 & 3,359 & 7,725 & 6,716 \\
$\begin{array}{l}\text { Unmarried children of United } \\
\text { States citizens................ }\end{array}$ & 6,462 & 6,097 & 4,648 & 2,525 & $\mathrm{I}, 955$ & 2,464 & 3,268 & 5,819 & 5,662 \\
\hline
\end{tabular}

U. S. Imimigration and Naturalization Service ANN. Rep. table 3 (I950-I954); I. \& N. Reporter, Nov. 1955, p. 28. 
adopted children and parents of citizens. Such persons today receive a preference within quotas, but where the quota is small, mortgaged, or oversubscribed, the entry may be too long delayed. ${ }^{26}$ Somewhat related to family reunification is the motif of racial reunification. Racial groups whose ties with the homeland are still fresh may, for one reason or another, desire new immigration. This may proceed from a sympathy for those who are impoverished or frustrated, or from the closely related emotion of guilt: guilt of being well-situated while one's brethren are in want or distress. It may be supposed that as time passes, this identification will diminish, particularly if the new infusions are relatively small. But racial consciousness has, as we have noted, been somewhat more persistent than might have been expected.

Then, there is the much broader conception which has already been noted: that it is the destiny of America to be a haven for all strains of the human race. This is a sentiment which is woven from many strands. First is the idea that our own specific character depends on it; our genius, conceived as the product of racial amalgam, must be kept fresh. It is doubtful that this particular version is deeply felt by many people. And as immigration now stands, the totals involved are too small to be racially significant. A closely related and more valid idea is that if our culture is to remain vital and progressive it will do well to attract new and varied intelligence. This effect can be achieved by relatively small numbers well within present limitations, provided, of course, that space is left open for genius. This must be achieved by administrative discretion, though administrative discretion is not notably receptive to genius, which is apt to be queer and radical. The present law does, as has been seen, allow the Attorney General to give preference to skills which are "urgently needed" and which will be "substantially beneficial" to our "cultural interests." This, undoubtedly, gives very broad discretion, but the Attorney General should not be required, at least in connection with cultural interest, to certify urgent need.

This notion of the destiny of America is also linked to the Christian concept of brotherhood. There are those-they must be very few-who believe that the Christian ethic condemns all barriers. A larger number, which, however, probably falls far short of a majority, though it does not accept the standard as absolute, does admit the claim of brotherhood. In its view, a nation, to be a significant and valuable organism and to perform its function, must maintain its coherence. This group would, thus, not deny that a nation may protect itself from unlimited immigration. It would be argued that in the end, the world would be no better off and, indeed, perhaps worse. The vast forces working toward overpopulation would be in no way alleviated or mitigated by wholesale migration to the less heavily settled areas; indeed, they would be given further encouragement. America might then become just one more overpopulated area and robbed of her capacity to make any special or significant contribution. But America, it would be argued, should, at

${ }^{20}$ See Schwartz, supra note $\mathrm{I}$, at 326 . 
the same time, proclaim its adherence to the concept of brotherhood by admitting some members of every race on a nondiscriminatory basis. This would serve as a symbolic recognition of the ideal.

This concept calls for a standing law under which, each year, there is admitted some given number of immigrants. Obviously, this function points to no particular number. It should not be ridiculously small. Should it be divided into nationalorigin quotas? There are those who feel that any quota based on national origin is invidious, since it recognizes the fact of race, or at the least must be based on some arbitrary ratio. It would appear, however, that abstractly considered, a nationalorigins system would not, ipso facto, give offense if the scheme were not based on a concept or intention to discriminate. But it seems fairly certain that any scheme that would be accepted by Congress would discriminate at least against the Orientals. It is also arguable that race should be recognized in the sense that the people of each nation should receive a "fair" opportunity to come here. This might be based on their relative populations. The fact is, however, that "over population" with its consequent distress is much more severe in some countries, and it might be thought that a "fair" formula should recognize it. One suggestion is first-come-firstserved, with a provision that no nation should have more than a certain percentage of the whole. ${ }^{27}$ This would appear to give everyone an equal opportunity and to avoid the difficulties of formulating a national-quota system.

The refugee, particularly from political or religious persecution, and, in a lesser degree, from national calamity, makes the most intense appeal to the emotions of brotherhood; and the most significant relaxations of our standing policy have been the two acts designed to provide a haven for European refugees. Such legislation must almost necessarily be ad hoc. It will, of course, as a rule, operate in terms of national or racial origin.

It is of some significance that the Refugee Relief Act of 1953 included a quota for Italians, Greeks, and Dutch (irrespective of their "refugee" character) who were within the family preference quotas of the standing act, and the 1954 amendment provides that the "refugee" and family preference quotas are to be interchangeable. This would permit, for example, 60,000 Italians to enter within the two and one half years of the act as compared with the regular annual quota of 5,600 , though there may be a question whether there are 60,000 Italians who are within the preference class. The act, thus, goes a little way toward recognizing the special population problems of these three countries. Indeed, it is doubtful that the "refugee" concept was relevant to the Italian, Dutch, and Greek situation in the first place. There is evidence that those responsible for the legislation did not intend it to be workable, but were making a rather empty gesture in the direction of these three countries which had specific overpopulation problems and, in the case of at least one or two of them, important lobbies in this country. Is it, then, a function of immigration

${ }^{27}$ This is the proposal of the Lehman bill, supra note 18 , which set a limit of $10 \%$ of the annual total on immigration from any country. 
to relieve world overpopulation? Clearly, it cannot be in any general sense. That would be to return to the policy of unlimited immigration. But it is argued that in Italy, for example, a net decline in the birth rate is in sight, and temporary relief may ease its immediate problems. Is it the theory, then, that an immediate problem of this sort is comparable to the refugee problem and makes a special appeal to the claims of brotherhood? Perhaps; but it would be more frank to recognize that we have now arrived at one more and perhaps one of the most important functions of immigration policy, namely as an instrument of foreign affairs.

The greatest failure of the McCarran-Walter Act was its failure to recognize the foreign policy function of immigration. It is true that, in its broad outlines, the act merely codified the policy of 1924. But it is the first fact of our national life that our world position has, since then, changed radically, though the I924 Act, by offending the Japanese, made its contribution to the deterioration of our foreign relations. There is a consensus that for our national welfare and security, we need the friendship and cooperation of other nations. Since we seek to lead under the banner of Democracy and Christian Brotherhood, our immigration policy should manifest a belief in those ideals. Therefore, even the many who do not believe in them or who do not, on balance, see their necessary application to immigration (and this is, perhaps, a substantial majority) can be lead, perhaps, to see the expediency in terms of foreign affairs of recognizing their relevance. It is true that Canada and Australia have, in the past, pursued discriminatory policies and may not have, thus, suffered in world estimation. But we are more vulnerable perhaps because our professions of virtue are more strident, perhaps because our power is greater, perhaps because we demand more insistently that others follow our leadership. In any case, our present quota system only serves to irritate. Indeed, as the refugee relief bills show, it does not even represent our actual policy.

The Italian, Greek, and Dutch clauses of the Refugee Relief Act are a somewhat special expression, however, of our foreign policy. These are, in a sense, discriminatory. There are other overpopulated areas (all of Asia, for example) to which we would not, I think, extend such relief. It is said-and with much truth-that the overpopulation problem in these European countries may be within view of solution so that our aid may hasten it, whereas this is not true of Asia. But this is not, I would suppose, the whole truth: these statutes would seem to be part of our policy of strengthening western Europe and cementing our alliances. It probably also reflects a realization that these stocks are no longer alien in American eyes. Finally, Congress may have preferred this solution to a major revision of the McCarran-Walter Act and hoped to mollify two of the strongest pressure groups behind immigration reform.

We should refer once more, at this point, to the policy of allowing free immigration from the Americas. This, as we have said, probably is intended to express a notion of American continental solidarity. It is a feature, in a sense, of the goodneighbor policy, and of our bid for hemisphere leadership. It, thus, may be thought 
of as another example of immigration policy as a function of foreign affairs. Viewed in the light of a rather narrow logic, it is discriminatory, ${ }^{28}$ but (in form at least) it is not racially discriminatory. In any case, since it is probably felt abroad that the Americas have a special community of interests, it is doubtful that it gives rise to resentment. ${ }^{20}$

If special treatment is to be given to the population problems of particular countries, ad hoc legislation rather than general reform may be the likely method. Recently, however, the President has proposed a modification of the standing law directed to the population problems of southern Europe. ${ }^{30} \mathrm{He}$ would add 65,000 to the total annual maximum and distribute this additional amount according to a formula based on actual sources of immigration since 1924 . This formula would govern not only the additional 65,000 , but unused numbers under the older segment of the total. It has been estimated that this would increase the southern European quota to about 125,000 as compared with the present quota of under I0,000. This, too, is a species of ad hoc solution. But that is unavoidable if (I) immigration policy is to be used as an instrument of foreign affairs, and (2) the bolstering of Europe and our influence there is to take precedence in our foreign policy. This discrimination may cost some losses in Asia, but that is, perhaps, but a minor aspect of a general policy which chooses to prefer Europe to Asia. It is, therefore, in a sense, inconsistent with an immigration policy expressing a more universal concept of brotherhood. But whatever the popular support for the President's proposal, it will be a small minority which will object to it on that ground.

${ }^{29}$ S. I206, 84th Cong, rst Sess. (1955), would bring the western hemisphere under the quota system. See Schwartz, stipra note I, at 336 , for the arguments pro and con.

${ }^{20}$ The following table shows the relation of western hemisphere immigration to all immigration.

\begin{tabular}{|c|c|c|c|c|}
\hline & Europe & $\begin{array}{l}\text { Central and South } \\
\text { America, Mexico } \\
\text { and West Indies }\end{array}$ & $\begin{array}{l}\text { Canada and } \\
\text { Newfoundland }\end{array}$ & Italy \\
\hline \multirow[t]{2}{*}{ 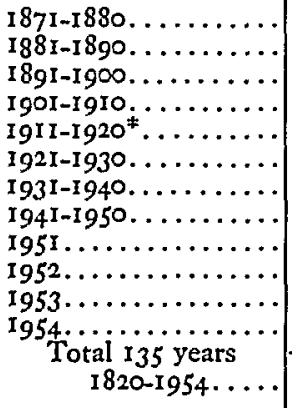 } & $\begin{array}{r}2,272,262 \\
4,737,046 \\
3,558,978 \\
8,136,016 \\
4,376,564 \\
2,477,853 \\
348,289 \\
621,704 \\
149,545 \\
193,626 \\
82,352 \\
92,121\end{array}$ & $\begin{array}{r}21,404 \\
\mathrm{r} 33,663, \\
35,661 \\
182,662 \\
401,486 \\
592,201 \\
51,510 \\
183,086 \\
21,751 \\
27,695 \\
41,367 \\
60,714\end{array}$ & $\begin{array}{r}383,640 \\
393,304 \\
3,311 \\
179,226 \\
742,185 \\
924,515 \\
108,527 \\
171,718 \\
25,880 \\
33,354 \\
36,283 \\
34,873\end{array}$ & $\begin{array}{r}55,759 \\
307,309 \\
651,893 \\
2,045,877 \\
1,109,524 \\
455,315 \\
68,028 \\
57,661 \\
8,958 \\
11,342 \\
8,432 \\
13,145\end{array}$ \\
\hline & $33,763,983$ & $1,730,351$ & $3,307,836$ & $4,8 \mathrm{I} 8,76 \mathrm{I}$ \\
\hline
\end{tabular}

* If account is taken of the fact that there was no immigration during the war years (1914-18), it will be seen that the high rate of immigration was continuing.

U. S. Immigration, and Naturalization Service ANN. Rep. table 4 (1954).

${ }^{30}$ See N. Y. Times, Feb. 9, 1956, p. 14, cols. 3-7. 
IV

\section{ConcLusion}

The traditional American policy of unlimited immigration was based essentially on economic and defense considerations. It gave rise, however, to the idea that immigration was necessary to the continued spiritual and cultural life of America; in part, because America's strength was based on its multiracial character, in part, because of a spiritual and religious obligation to all of mankind. This idea, however, was not universally accepted, perhaps not even by a majority of our people. It was most intensely entertained by racial groups still consious of their racial origin. The older stocks were either indifferent to such a conception or strongly opposed to it.

World War I put a temporary stop to immigration. It gave rise also to fear that our multiracial character was a threat to our security. In the meantime, the entire country had become settled, and the frontier had become closed. Now, voices were raised against further dilution of the assumed American racial character. And in the absence of any agreement on the purposes of immigration, these voices were heeded. A proposal entirely to suspend immigration for four years was rejected. A policy of limited immigration was adopted. In giving preferences to family connections and to farm laborers, it is suggested two motivations for immigration, but the numbers involved in these two preferences were not large, and inevitably, the total annual number had to be fixed arbitrarily. The only aspect of this legislation that was strongly felt was its discrimination against the southern Europeans. This was not a soundly considered policy, even from the point of view of its sponsors. Given the initial decision radically to curtail immigration, the number of possible immigrants of any one national origin was negligible, so that the gain did not balance the cost in hurt feelings.

The Immigration and Nationality Act of 1952 perpetuated the policy of 1924 . It gave a broader form to the family and special skills preferences. The Displaced Persons Act of 1948 and the Refugee Relief Act of 1953 somewhat increased the annual total and substantially disregarded the policy of discrimination against eastern and southern Europeans. It was based, in part, on humanitarian concepts, in part, on strengthening western Europe and winning its support for our foreign policy.

The present predicament is the need to develop a positive philosophy for immigration that will be persuasive enough to win popular support. Everyone can agree on immigration to meet our need for special skills; somewhat more problematic is its use to fill shortages in common and semiskilled jobs. And perhaps, everyone can agree on family reunification more or less in its present form. These two functions, however, account for only a very limited number of immigrants. Beyond this, the possible functions of immigration are more debatable, at least in their appeal to public opinion. Among them are these: to maintain our racial variety and energy; to keep our culture fresh and progressive; to attest our belief in universal brotherhood; to testify to our sympathy for those in any way in need. Each of 
these has its supporters, each its violent opponents, and each, a large number, perhaps a majority, of indifferents. If, however, the favoring minorities are important and insistent enough, their support may suffice to enact a law that gives some recognition to these functions.

At the present moment, it would appear to be most feasible to unite the largest number of persons (it could even be a majority) on immigration as an instrument of foreign affairs. Under this guise, some of the same functions would be given recognition. If America be, in fact, a haven, even on a token basis, of oppressed or hopeless peoples, its claim to lead the world in the name of brotherhood is more persuasive. Some possible uses in foreign affairs, however, move in a somewhat contradictory direction. If we give special treatment to Italy and Greece to enable them to solve their overpopulation problem, we are pro tanto discriminating. It is clear that under a policy of limited immigration, any general theory of discrimination based on assumptions as to our national character is a costly and stupid expression of mere prejudice. If it becomes a question, however, of admitting exceptional numbers of any one national origin, it may be necessary to reckon with assumptions concerning the racial norm.

Most of these suggested rationalizations give little clue as to fixing a total annual number under a standing law. It must, in the last analysis, be arbitrary. President Eisenhower in his recent message says that "economic growth over the last thirty years" justifies an increase from 150,000 to 220,000 . But nothing gives us any clue to why it should be one or the other or any other number. He has in mind that, by one device or another, further room will be found for Italians, and the Italian problem is, at the moment, one of our most crucial concerns. Essentially, the Italian problem is, an ad hoc problem. Indeed, with respect to certain functions of immigration, the question of totals and of quotas is always ad hoc. In Canada and Australia, the authorities are given unlimited discretion to decide totals and quotas from day to day. But such a solution would be unworkable in the United States. Those countries do not have, as yet, large racial and antiracial pressure groups. We do, and Congress alone is equal to the conflicts which they generate. Congress may, at times, deal with the problem by an avowed ad hoc solution, but there is a political limit to these solutions, and then it may become necessary to formulate the semitemporary in the guise of a more general scheme. 